\title{
IMPACT OF PARAMETERS OF IRRADIATION OF POTATO BULBS WITH UVC ON SELECTED COEFFICIENTS OF ASSESSMENT OF COLOUR OF FRIES DETERMINED WITH CIE L*A*B* METHOD
}

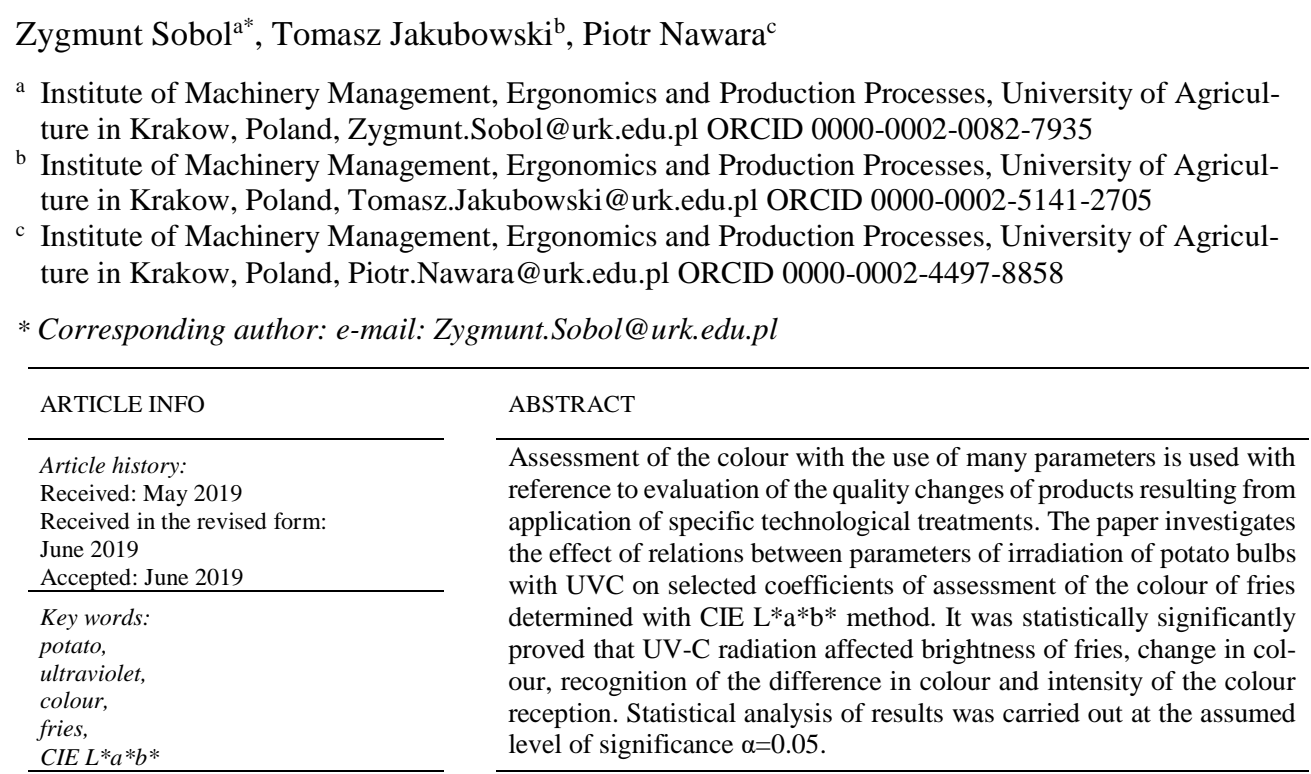

\section{Introduction}

Colour is one of the most important parameters that serves for assessment of quality of raw materials and food products. It is used by producers, processing technologists, and consumers. Assessing the colour with number of parameters refers, for example, to determination of quality changes in products that result from specific technological treatments. Przybylski (2008) analysed the colour to distinguish high quality pork. Zapotoczny and Zielińska (2005) investigated a change in colour of a non-uniform material, namely carrot roots, Śmigielska et al., (2013) traced the impact of use of starch as a thickener on the change of colour of ketchup. Tomaszewska and Neryng (2007) described the colour of ready products from potatoes obtained at variable parameters of thermal processing and the time of storing and prepared according to technologies of sudden cooling. Cendrowski et al., (2012) investigated the impact of production methods and long-term storing on the colour of beach rose petals preserves, and Rój and Przybyłowski (2012) determined the colour of natural yoghurt in re- 
lation to the content of fat. Ciurzyńska et al., (2011) investigated the impact of osmotic dehydration on the colour of freeze-dried strawberries and Gościnna et al., (2014) determined the change of colour of beetroot juice in relation to the conditions of heating. Pasławska et al., (2010) considered a change of parameters of colour of berries resulting from drying, storing and rehydration. Sakowski and Janiszewska (2013) investigated a change of the carrot juice colour as a result of its treatment with ultraviolet and Mieszkalska and Piotrowski (2014) analysed application of colour models for assessment of dried plant raw material. For description of the colour even more often the model CIE $L^{*} a^{*} b^{*}$ is applied which may be used for analysis of the quality of fruit, vegetables, dairy and potato products (Maskan 2001; Pedreschi et al., 2006; Rój, Przybyłowski 2012; Sansano et al., 2015). CIE $L^{*} a^{*} b^{*}$ model has a significant predominance over the remaining systems since it has a separate channel of brightness and chromatic components informing (Pytko 2010) on the content of one of the colours: green, violet-red, blue and yellow (Pytko 2010). UV-C radiation (100-280 nm) with the length of waves of $253.7 \mathrm{~nm}$ has sterilizing properties and is used in food industry (Corrales et al., 2012) and in crop protection (patent US 2009/0272029 A1). According to the mentioned patent specification (US 2009/0272029 A1) there is a destructive impact of UVC on some crop pathogens, such as: Botrytis cinerea $\mathrm{L}$. and Phytophthora citricola L. (Aiking et al., 2009). UV-C radiation was also used as a sporicidal treatment with reference to corn seeds (Zea mays L.) hybrids San Juan and H-159 (Páez et al., 2011). Cools et al., (2014) used ultraviolet to determine the effectiveness of UV-C as a germination inhibitor of potato seedlings.

The aim of the paper was to determine the impact of radiation of potato bulbs with UVC on selected coefficients of assessment of the colour of fries determined with CIE L*a*b* method.

\section{Material and methods}

Storage and laboratory experiments were performed in 2016-2017. Potato bulbs of Innovator cultivar were used as a material for research. Innovator cultivar is one of the most eagerly used cultivars in production of fries by European and Polish companies (Lisińska 2006). It is an early cultivar, culinary type B with bulbs of a regular shape, round and oval, of the average content of starch $14.6 \%$. This cultivar is very resistant to darkening of the pulp of raw material and after cooking it is suitable for storing. Bulbs are kept in a refrigerator in single layers on the openwork substrate. Temperature of storing was $10^{\circ} \mathrm{C}$ and relative moisture of air $90-95 \%$. Intermediate products for fries were potato columns $10 \times 10 \mathrm{~mm}$ and length of $60 \mathrm{~mm}$. Columns were cut off along the longest axis of bulbs, determined between a top and umbilical part. Tests were carried out after 3 months of storing. A stand for radiation of the biological material with UV-C is a chamber equipped with a radiator TUV UV-C NBV $15 \mathrm{~W}$ type (Jakubowski et al., 2012, 2013, 2015). A structure of the radiator enabled smooth regulation of the height over the bottom of the chamber within 0.4 and 1.0 and was equipped with a precise time switch (model AURATON 100). Potato bulbs during radiation were located on the flat, metal bottom with the area of $0.52 \mathrm{~m}^{2}$. UV-C radiation of potato bulbs were differentiated assuming the following parameters: (1-3) - radiation 30 minutes on one side of the bulb (2-4) - radiation 15 minutes from two opposite sides of the bulb, 0 - control sample (without radiation). Radiation was carried out two days before formation of intermediate 
Impact of parameters...

products $(1,2)$ and before storage $(3,4)$. Temperature of frying was $170^{\circ} \mathrm{C}$ and frying time was 15 minutes. Fries were fried at one stage to the moment of achieving proper sensory parameters for the ready product. The relation of the mass of a batch (intermediate product) to the mass of frying fat was 1:15. Frying time was determined in a separate initial experiment by analysis of a sensory input of a group of persons that assess them. Fried fries were dried of excess of oil in two stages: 1 - on a mesh shaken substrate, 2 - on a paper absorptive material. Colour of fries was assessed with the use of CIE $L^{*} a * b *$ method with instrumental measurement of colour during which element values were registered: $\mathrm{L}^{*}$ - brightness, chromaticity, $a^{*}$ - (from red to green), $b^{*}$ - (from yellow to blue). Figure 1A presents a structure of the stand for measurement of the colour consisting of Basler aca -4600-10uc camera connected to a computer with U3-PCIE1XG205 card served by Pylon 5 program. Before the study, the camera was calibrated on the colour palette of controlled white and black hues (fig. $1 \mathrm{~B})$ placed on the white background to improve the correct mapping of the colour. Basler aca-4600-10uc camera is equipped with a sensor Aptina MT9F002 CMOS with resolution $4608 \mathrm{px}$ x $3288 \mathrm{px}$ and size of pixel $1.4 \mu \mathrm{m}$ x $1.4 \mu \mathrm{m}$. Then, with a graphic environment of LabView2015 CIE $L^{*} a * b *$ colours were marked in 3 points for the investigated objects. In each object 12 measurements of colour were made.

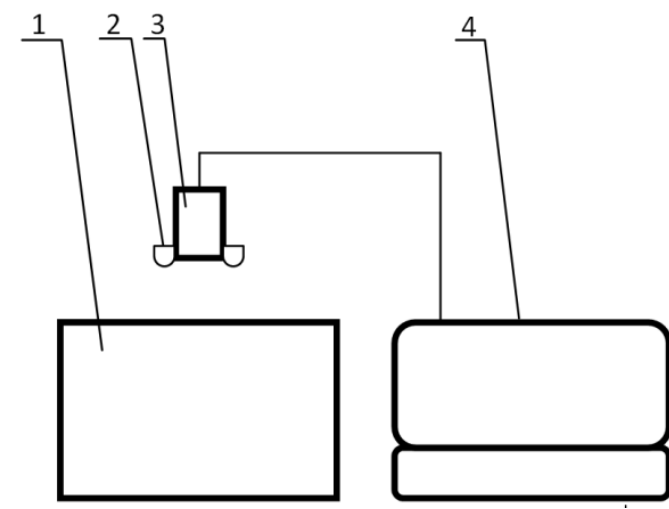

A

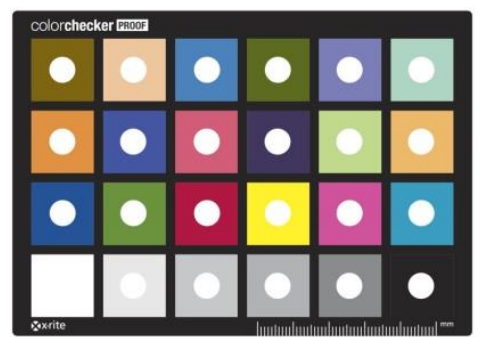

B

Figure 1. A-structure of the stand: 1 - chamber, 2 - lighting, 3 -camera, 4 -computer, $B$ - palette of control colours: X-Rite ColorChecker PROOF

Temperature of the investigated samples was equal to the temperature of surrounding and was $20^{\circ} \mathrm{C}$. Each object of studies was analysed with regard to colour on the white background. For each combination of the experiment measurement on 10 fries was performed in two iteration.

Based on the values of parameters of colour L*, a*, b*the following were calculated (Draft Standard CIE DS 014-4.3/E: 2007; Wrolstad, Smith 2010; Zielińska, Markowski 2012):

Difference in brightness $\Delta \mathrm{L}^{*}$ :

$$
\Delta \mathrm{L} *=\mathrm{L}^{*}{ }_{1}-\mathrm{L}^{*}
$$


Difference of chromaticity of $\Delta \mathrm{a}^{*}$ parameter:

$$
\Delta \mathrm{a}^{*}=\mathrm{a}^{*}{ }_{1}-\mathrm{a}^{*}
$$

Difference of chromaticity of $\Delta * b$ parameter:

$$
\Delta \mathrm{b}^{*}=\mathrm{b}^{*}{ }_{1}-\mathrm{b}^{*}
$$

Total difference of colour $\Delta \mathrm{E}^{*}$ :

$$
\Delta \mathrm{E}^{*}=\left(\left(\Delta \mathrm{L}^{*}\right)^{2}+\left(\Delta \mathrm{a}^{*}\right)^{2}+\left(\Delta \mathrm{b}^{*}\right)^{2}\right)^{0,5}
$$

Difference of colour (change in colour saturation) $\Delta C^{*}$ :

$$
\Delta \mathrm{C} *=\left(\left(\mathrm{a}^{*}\right)^{2}+\left(\mathrm{b}^{*}\right)^{2}\right)^{2,5}-\left(\left(\mathrm{a}_{0}\right)^{2}+\left(\mathrm{b}_{0}\right)^{2}\right)^{0,5}
$$

Difference in tone (shade) $\Delta H^{*}$ :

$$
\Delta \mathrm{H}^{*}=\left(\left(\Delta \mathrm{E}^{*}\right)^{2}-(\Delta \mathrm{L} *)^{2}-\left(\Delta \mathrm{C}^{*}\right)^{2}\right)^{0,5}
$$

The obtained results of research were analysed with the use of STATISTICA 13.3 software on the assumed significance level of $\alpha=0.05$. Regularity of distribution (Shapiro-Wilk test) and uniformity of variance in samples (Levene test). Analysis of variance was applied with Duncan test.

\section{Results and discussion}

Table 1 shows that all analysed coefficients of assessment of the colour of fries determined with CIE L*a*b* $\left(\Delta \mathrm{L}^{*}, \Delta \mathrm{a}^{*}, \Delta \mathrm{b}^{*}, \Delta \mathrm{E}^{*}, \Delta \mathrm{C}^{*}, \Delta \mathrm{H}^{*}\right)$ method were statistically significant with regard to relations between parameters of radiation of potato bulbs.

Table 1.

Analysis of variance in single classification. Impact of relations between parameters of radiation of potato bulbs on selected coefficients of assessment of the colour of fries determined with $C I E L^{*} a^{*} b^{*}\left(\Delta L^{*}, \Delta a^{*}, \Delta b^{*}, \Delta E^{*}, \Delta C^{*}, \Delta H^{*}\right) \operatorname{method}$

\begin{tabular}{lcccccc}
\hline $\begin{array}{l}\text { Parameters } \\
\text { of analysis of } \\
\text { variance }\end{array}$ & $\begin{array}{c}\text { Difference in } \\
\text { brightness } \\
\Delta \mathrm{L}^{*}(-)\end{array}$ & $\begin{array}{c}\text { Difference } \\
\Delta \mathrm{a}^{*}(-)\end{array}$ & $\begin{array}{c}\text { Difference } \\
\Delta \mathrm{b}^{*}(-)\end{array}$ & $\begin{array}{c}\text { Total } \\
\text { difference } \\
\text { in colour } \Delta \mathrm{E}^{*}(-)\end{array}$ & $\begin{array}{c}\text { Difference } \\
\text { in colour } \\
\Delta \mathrm{C}^{*}(-)\end{array}$ & $\begin{array}{c}\text { Difference } \\
\text { in tone } \\
(\text { shade }) \\
\Delta \mathrm{H}^{*}(-)\end{array}$ \\
\hline $\begin{array}{l}\text { F Snedecor } \\
\text { statistics }\end{array}$ & 12.026 & 13.541 & 14.082 & 9.076 & 14.071 & 8.501 \\
\hline $\begin{array}{l}\text { Test } \\
\text { probability }\end{array}$ & 0.000 & 0.000 & 0.000 & 0.000 & 0.000 & 0.000 \\
\hline
\end{tabular}

Differences in brightness $\Delta \mathrm{L}^{*}$ are within -5.012 and 1.208 (tab. 2), (fig. 2). Values of differences in brightness occurring in particular relations were divided into two homogenous groups: group (a) $(0-3,0-4,1-3,1-4,2-3,2-4)$ and group (b) $(0-1,0-2,1-2,3-4)$ tab. 2 . All values of the homogeneous group (b) assume negative values and this indicates that in these relations between parameters of radiation fries darkened. While, values of difference in brightness of fries in relations $0-1$ and 0-2 are positive, thus, they become slightly lighter. 
Impact of parameters...

Values of difference in brightness of fries in the remaining relations assume low negative values, which results in slight differences in brightness.

Table 2.

Average values of selected coefficients of assessment of colour of fries determined with CIE $L^{*} a^{*} b^{*}\left(\Delta L^{*}, \Delta a^{*}, \Delta b^{*}, \Delta E^{*}, \Delta C^{*}, \Delta H^{*}\right)$ method

\begin{tabular}{|c|c|c|c|c|c|c|}
\hline $\begin{array}{l}\text { Relations } \\
\text { between the } \\
\text { parameters } \\
\text { of radiation }\end{array}$ & $\begin{array}{c}\text { Difference in } \\
\text { brightness } \\
\Delta \mathrm{L}^{*}(-)\end{array}$ & $\begin{array}{c}\text { Difference } \\
\Delta \mathrm{a}^{*}(-)\end{array}$ & $\begin{array}{c}\text { Difference } \\
\Delta \mathrm{b}^{*}(-)\end{array}$ & $\begin{array}{c}\text { Total } \\
\text { difference } \\
\text { in colour } \\
\Delta \mathrm{E}^{*}(-)\end{array}$ & $\begin{array}{c}\text { Difference in } \\
\text { colour } \\
\Delta \mathrm{C}^{*}(-)\end{array}$ & $\begin{array}{c}\text { Difference in } \\
\text { tone (shade) } \\
\Delta H^{*}(-)\end{array}$ \\
\hline $0-1$ & $1.208_{(b)}$ & $-5.031_{(\mathrm{c})}$ & $6.678_{(c)}$ & $14.110_{(\mathrm{b} . \mathrm{d})}$ & $7.252_{(\mathrm{c})}$ & $4.586_{(a . b)}$ \\
\hline $0-2$ & $0.566_{(b)}$ & $-4.265(\mathrm{c})$ & 2.662 (b.c) & $13.574_{(\text {b.d) }}$ & $3.180_{\text {(b.c) }}$ & 4.148 (a.b) \\
\hline $0-3$ & $-3.651_{(a)}$ & $3.689_{(a)}$ & $-16.217_{(\mathrm{a})}$ & 18.015 (a.b) & -16.092 (a) & $5.585_{(b . c)}$ \\
\hline $0-4$ & $-3.804(a)$ & 3.592 (a) & -16.045 (a) & 17.650 (a.b) & -15.926 (a) & 5.496 (a.b.c) \\
\hline $1-2$ & $-0.6429_{(b)}$ & $0.767_{(\mathrm{a})}$ & $-4.016(b)$ & 8.304(d.e) & $-4.071_{(b)}$ & $3.487_{(\text {a.b) }}$ \\
\hline $1-3$ & -4.859 (a) & $8.720_{(b)}$ & $-22.895_{(a)}$ & $28.404_{(\mathrm{c})}$ & $-23.343_{(\mathrm{a})}$ & $9.583(\mathrm{e})$ \\
\hline $1-4$ & $-5.012(a)$ & $8.623_{(b)}$ & $-22.723_{(a)}$ & $25.029_{\text {(a.c) }}$ & $-23.178_{(\mathrm{a})}$ & 7.232 (c.d) \\
\hline $2-3$ & -4.217 (a) & 7.954(b) & $-18.879_{(a)}$ & 22.054 (a.c) & $-19.272_{(\mathrm{a})}$ & 7.577 (c.d.e) \\
\hline $2-4$ & $-4.370_{(a)}$ & $7.857_{(\mathrm{b})}$ & $-18.707_{(\mathrm{a})}$ & $24.169_{\text {(a.c) }}$ & $-19.106_{(a)}$ & $8.928_{(\text {d.e })}$ \\
\hline $3-4$ & $-0.153_{(b)}$ & $-0.097_{(\mathrm{a})}$ & $0.172_{\text {(b.c) }}$ & $6.427_{(\mathrm{e})}$ & $0.166_{\text {(b.c) }}$ & $3.121_{(\mathrm{a})}$ \\
\hline
\end{tabular}

(a)....(e) -Homogeneous groups

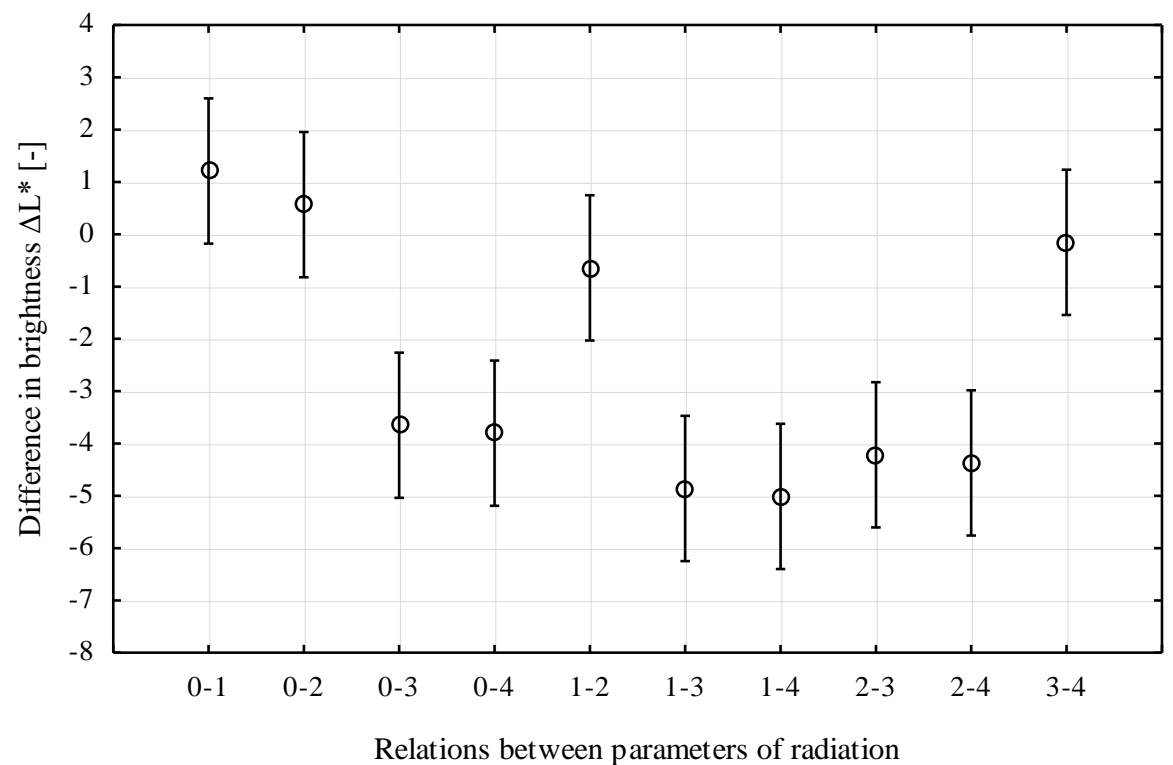

Figure 2. Impact of radiation parameters of $U V$-C rays on difference in brightness $\Delta L^{*}$ of fries 
Values of differences in chromaticity of $\Delta \mathrm{a}^{*}$ parameter: are within -5.031 to 8.720 (tab. 2, fig. 3). Values of difference of chromaticity of $\Delta \mathrm{a}^{*}$ parameter that occur in particular relations between radiation parameters were divided into three homogeneous groups: group (a) $(0-3,0-4,1-2,3-4)$, group (b) $(1-3,1-4,2-3,2-4)$ and group (c) $(0-1,0-2)$ (tab. 2). Small values of difference of chromaticity of $\Delta \mathrm{a}^{*}$ parameter, homogeneous groups (a) prove a slight change of this parameter and cause a slight increase of intensity of the colour of fries towards a red colour. Values of differences in chromaticity of $\Delta \mathrm{a}^{*}$ parameter: distinguished in a group (b) show a clear increase of the colour of fries towards a red colour (increase in browning). Negative values of difference of chromaticity of $\Delta \mathrm{a}^{*}$ parameter in group (c) justify a difference in the colour of fries towards a green colour.

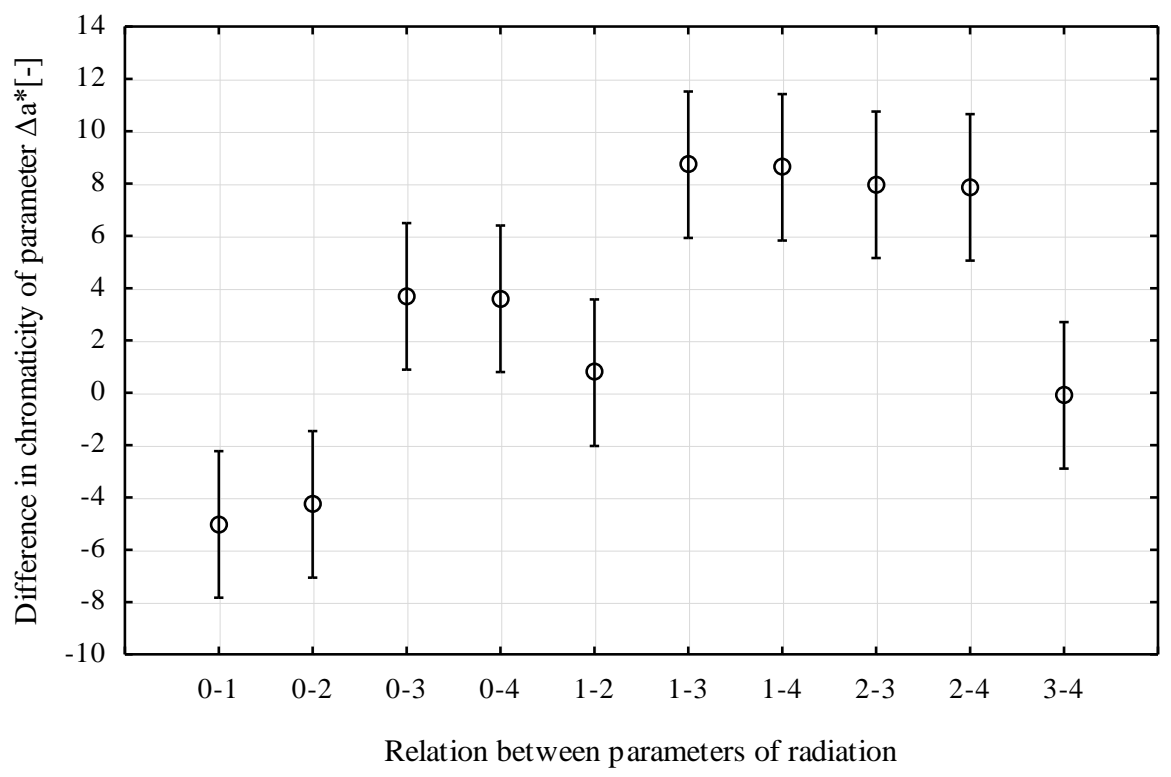

Figure 3. Impact of radiation parameters of $U V$-C rays on difference in brightness $\Delta a^{*}$ of fries

Values of differences of chromaticity of $\Delta * \mathrm{~b}$ parameter are from -22.895 to 6.678 (tab. 2 , fig. 4). Values of difference of chromaticity of $\Delta \mathrm{b}^{*}$ parameter that occur in particular relations between radiation parameters were divided into three homogeneous groups: group (a) $(0-3,0-4,1-3,1-4,2-3,2-4)$, group (b) $(0-2,1-2,3-4)$ and group (c) $(0-1,0-2)$ (tab. 2). Considerable negative values of chromaticity of $\Delta b^{*}$ parameter in the homogeneous group (a) prove that the colour of fries in relations between radiation parameters aims at the change in colour towards blue. Relating a direction of the change of difference in chromaticity of $\Delta \mathrm{a}^{*}$ parameter of the homogeneous group (b) and a change of difference in chromaticity of $\Delta b^{*}$ 
parameter of a homogenous group (a) (relations: 1-3, 1-4, 2-3, 2-4) and a difference in brightness of fries $\Delta \mathrm{L}$, for these relations, maintains changes of the colour of fries towards a lesser brightness and the increase of browning. Values of difference in chromaticity of $\Delta \mathrm{b}^{*}$ parameter in the homogeneous group (b) prove slight changes of the colour (rather towards yellow) while from group (c) a considerable change of the colour towards yellow.

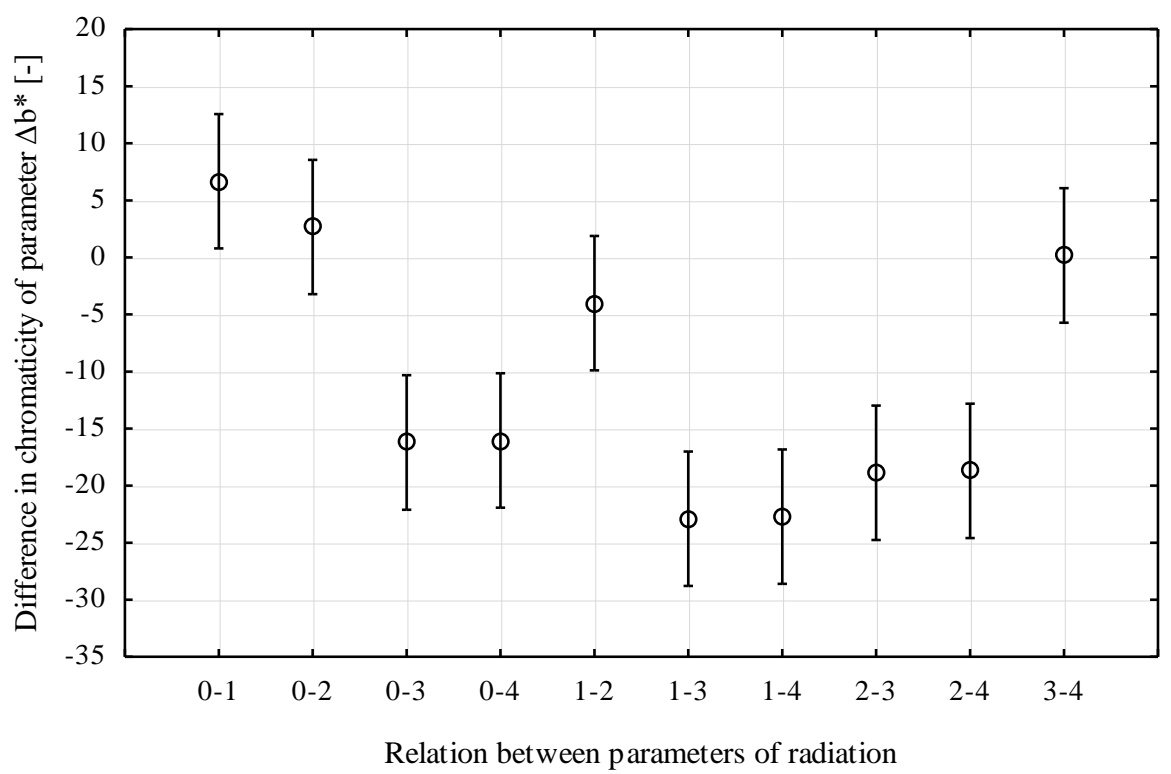

Figure 4. Impact of radiation parameters of UV-C rays on difference of chromaticity of parameter $\Delta b^{*}$ of fries

Values of the total difference in colour $\Delta \mathrm{E}^{*}$ change from 6.427 to 28.404 (tab. 2) (fig. 5) and they are included in the considerable colour deviation (above 5) recognised even by a non-experienced person (Wrolstad, Smith 2010). Value of the total difference in colour $\Delta \mathrm{E}^{*}$ were divided into five homogeneous groups: group (a) $(0-4,0-3,2-4,1-4)$, group (b) $(0-2,0-1,0-4,0-3)$, group (c) $(2-3,2-4,1-4,1-3)$, group (d) $(1-2,0-2,0-1)$, group (e) $(3-4,1-$ $3)$. Values of the total difference of colour $\Delta \mathrm{E}^{*}$ : of homogeneous groups $(\mathrm{a}, \mathrm{b}, \mathrm{c})$ indicate that recognisability of a difference in colour of fries with sight for those relations between parameters of radiation of bulbs is noticeably clear and easy to determine.

Values of difference in colour (changes of colour intensity) $\Delta \mathrm{C}^{*}$ are within -23.343 and 7.252 (tab. 2, fig. 6). Values of difference in colour $\Delta \mathrm{C}^{*}$ parameter were divided into three homogeneous groups: group (a) $(1-3,1-4,2-3,2-4,0-3,0-4)$, group (b) $(1-2,3-4,0-2)$ and group (c) (3-4, 0-2, 0-1). In the homogeneous group (c) differences of colour assumes positive values, thus it may be said that it results in the increase of intensity of reception of the colour of fries. The remaining values $\Delta \mathrm{C}^{*}$ were negative and this proves a decrease of intensity of the reception of the colour. 
Zygmunt Sobol, Tomasz Jakubowski, Piotr Nawara

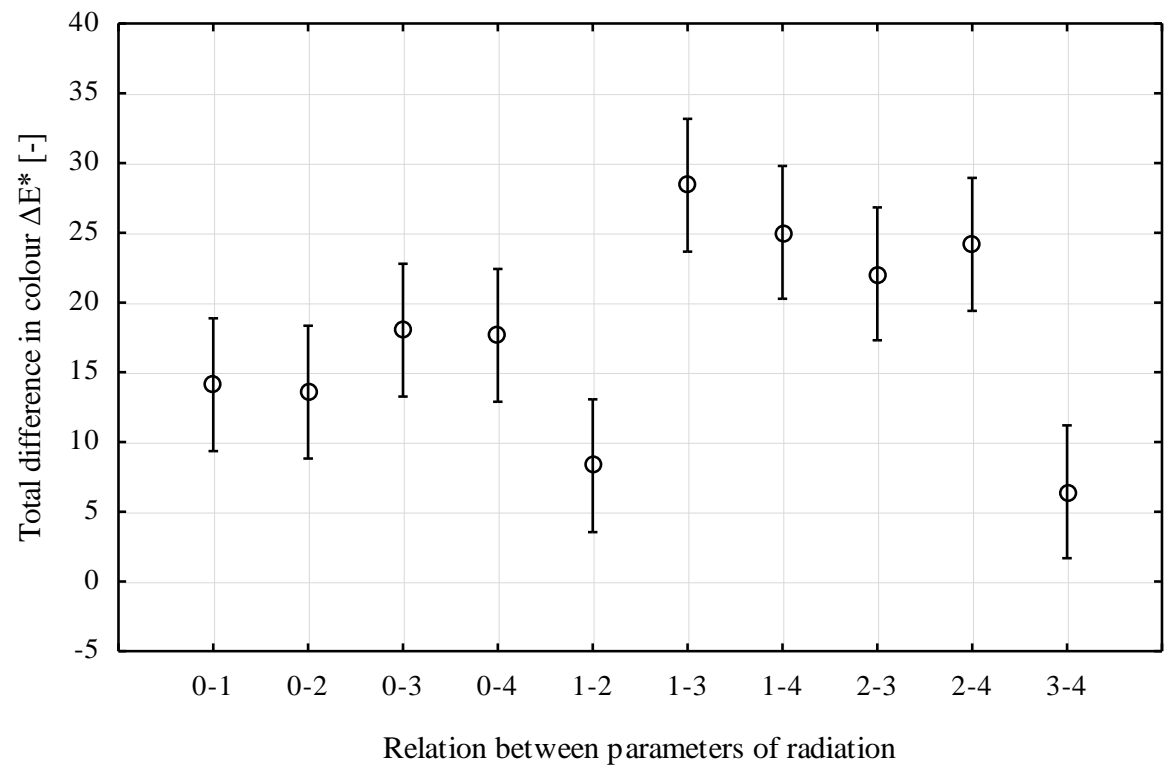

Figure 5. Impact of radiation parameters of $U V$-C rays on the total difference in brightness $\triangle E^{*}$ of fries

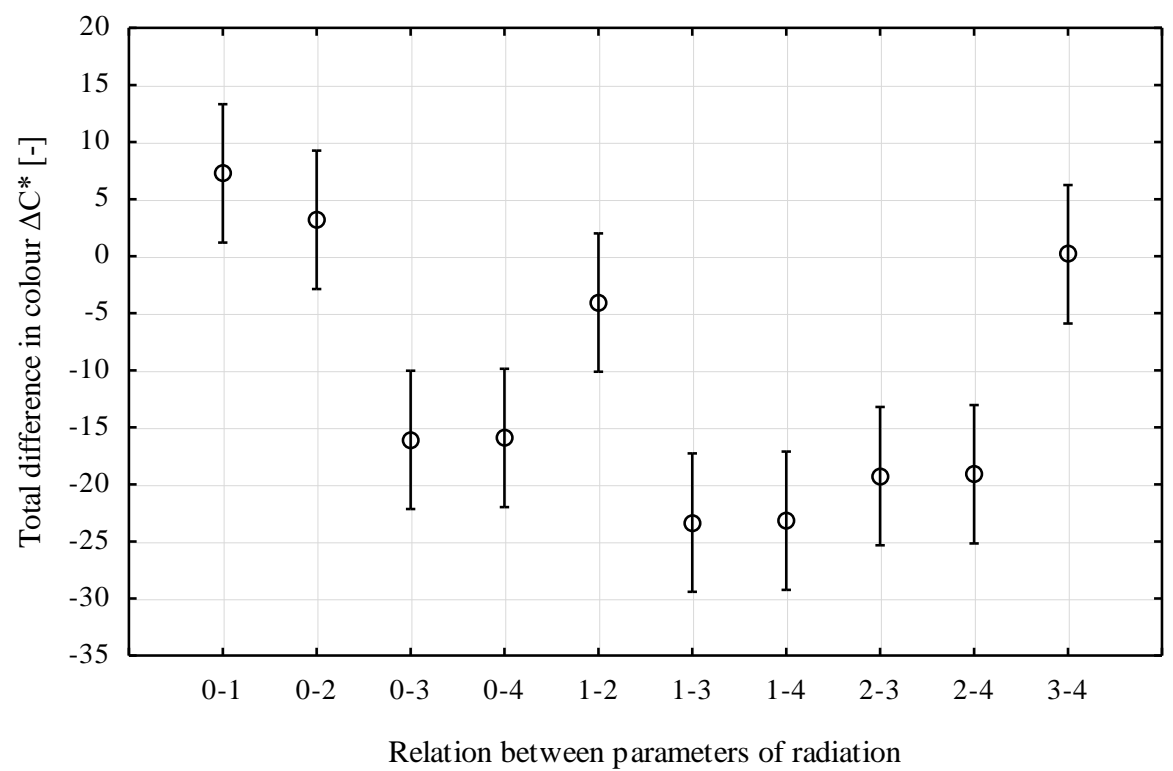

Figure 6. Impact of radiation parameters of $U V-C$ rays on the difference in brightness (change of intensity of colour) $\Delta C^{*}$ of fries 
Impact of parameters...

Values of difference in tone (shade) $\Delta \mathrm{H}^{*}$ of the colour of fries were within 3.121 and 9.583 (table 2, fig. 7). Values of $\Delta \mathrm{H}^{*}$ due to relations between parameter of bulbs were divided into five homogeneous groups: group (a) $(3-4,1-2,0-2,0-1,0-4)$, group (b) $(1-2,0-$ $2,0-1,0-4,0-3)$, group (c) $(0-4,0-3,1-4,2-3)$, group (d) $(1-4,2-3,2-4)$, group (e) $(2-3,2-4$, 1-3). Values of a difference in shade $\Delta \mathrm{H}^{*}$ acc. to the standard ISO 12647-7 assumes a maximum tolerance in basic colours at the level of 2.5. In particular homogeneous groups, visible differences in shade appear.

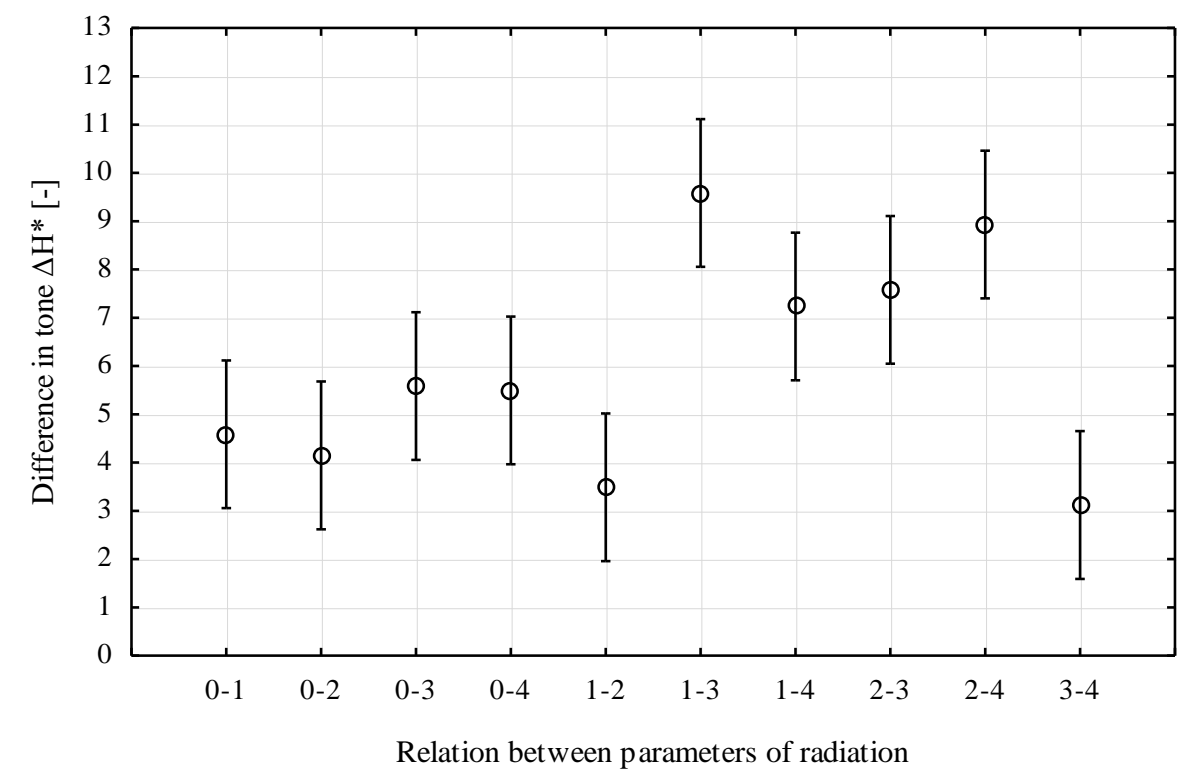

Figure 7. Impact of radiation parameters of $U V$-C rays on difference in tone (shade) $\Delta H^{*}$ of fries

Ultraviolet in the band $\mathrm{C}$ - one of the most active physical factors that induces mutations permeate the potato bulb to the depth of periderm of about $2 \mathrm{~mm}$ and directly adjusting pulp (Jakubowski et al., 2015). Thus, significant changes in the course of biochemical processes caused by UV-C radiation should be searched for around periderm Reddivari et al., (2007) emphasise that activity of ultraviolet on biological material causes its photochemical reaction in the form of photoisomeration which may cause a transformation of flavonoids into its another isomer as a result of photons activity. Permission of UV-C into tissue and its dispersion causes the state of particle induction which leads to the phenomenon of ejection of electrons from external orbits to the levels of higher energy. This results in formation of pirymid dimers which dislocate DNA structure disabling thus a correct course of replication. According to information provided by Slimestad et al., (2008) flavonoids (polyphenols, $\mathrm{C}_{6} \mathrm{C}_{3} \mathrm{C}_{6}$ ) play a protective function against UV radiation and have antioxidant properties. This ability may thus stop or delay the oxidation process of some substances in a plant (Xiuhong et al., 2012). If an assumption is made that UV-C influences a plant not only mutagenically but also 
causes an abiotic stress, then, because of such activity, metabolism may change into increase of production of secondary metabolites - as the mentioned flavonoids. Contents of polyphenols in potato bulbs is within 5.21 and $6.69 \mathrm{mg} \cdot 100 \mathrm{~g}^{-1}$ of fresh mass of flavonoids (mainly kaempferol, myricetin, luteolin). (Xiuhong et al., 2012, Ezekiel et al., 2013, Albishi 2013, Rytel et al., 2014 Wierzbicka et al., 2015). UV-C may, thus influence not only formation of flavonoids but also processes of transformations of simple sugars related therewith. This radiation may directly influence the reduction of simple sugars or its activity triggers mechanisms supporting sugars flushing by immersion in water. The effect of such a described permissible mechanism would be a change of the colour of fries after its thermal processing.

\section{Conclusions}

1. Relations between a control sample and parameters of radiation of bulbs 1, 2 carried out two days before formation of intermediate products indicate the increase of the brightness of fries, change of colour of fries towards green and yellow with a clear recognizability of a difference in colour, increasing intensity of colour reception and the slightest visible difference in shade.

2. Relations between the control sample and parameters of radiation of bulbs 3,4 carried out two days before the period of storing indicate the increase of the brightness of fries, change of colour of fries towards red and blue with a clear recognizability of a difference in colour, decreased intensity of colour reception and a visible difference in shade.

3. The biggest changes (in absolute values) of the investigated coefficients of the assessment of the fries colour determined with CIE $\mathrm{L}^{*} \mathrm{a}^{*} \mathrm{~b}^{*}\left(\Delta \mathrm{L}^{*}, \Delta \mathrm{a}^{*}, \Delta \mathrm{b}^{*}, \Delta \mathrm{E}^{*}, \Delta \mathrm{C}^{*}, \Delta \mathrm{H}^{*}\right)$ method occurred in relations between parameters of radiation of bulbs (1-3, 1-4, 2-3, 2-4).

\section{References}

Aiking, A., Verheijen, F. (2009). Methods for treating live plants or live plant parts or mushrooms with UV-C light. Clean Light Wageningen, US 2009/0272029 A1, 5 November 2009, Numer zgłoszenia: $12 / 083,994$

Albishi, T., John, J. A., Al-Khalifa, A. S., Shahidi, F. (2013). Phenolic content and antioxidant activities of selected potato varieties and their processing by-products. Journal of Functional Foods, 5, 590600.

Cendrowski, A., Mitek, M., Siestrzewitowska, I. (2012). Wpływ procesu technologicznego na zawartość antocyjanów i barwę konfitur z płatków róży pomarszczonej (rosa rugosa). ŻYWNOŚĆ. Nauka. Technologia. Jakość, 5 (84), 47-59.

Ciurzyńska, A., Lenart, A., Siemiątkowska, M. (2011). Wpływ odwadniania osmotycznego na barwę i właściwości mechaniczne liofilizowanych truskawek. Acta Agrophysica, 17(1), 17-32.

Cools, K., Alamar, M., Terry, L. (2014). Controlling sprouting in potato tubers using ultraviolet-C irradiance. Postharvest Biology and Technology 98, 106-114

Corrales, M., Souza, P., Stahl, M., Fernández, A. (2012). Effects of the decontamination of a fresh tiger nuts' milk beverage (horchata) with short wave ultraviolet treatments (UV-C) on quality attributes. Innovative Food Science and Emerging Technologies, 13, 163-168.

Draft Standard CIE DS 014-4.3/E: 2007- CIE Publication No. 15.2, Colorimetry.

Ezekiel, R., Singh, N., Sharma, S., Kaur, A. (2013). Benefi cial phytochemicals in potato - a review. Food Research International, 50. 487-496. 
Impact of parameters...

Gościnna, K., Walkowiak-Tomczak, D., Czapski, J. (2014). Wpływ warunków ogrzewania roztworów koncentratu soku z buraka ćwikłowego na parametry barwy i zawartość barwników betalainowych. Aparatura Badawcza i Dydaktyczna 2, 183-189.

ISO 12647-7:2016 Graphic technology - Process control for the production of halftone colour separations, proof and production prints - Part 7: Proofing processes working directly from digital data

Jakubowsk, T., Wrona, P. (2012). Effectiveness of UVC radiation influence on the development of tuber potato tuber crops. Part I - test stand. Acta Scientiarum Polonorum - Technica Agraria, 11(12), 33-41.

Jakubowski, T., Pytlowski, T. (2013). Influence of ultraviolet radiation on the growth, development and yielding of potato plants (preliminary studies). Agricultural Engineering, 3(145). 99-107.

Jakubowski, T., Pytlowski, T. (2015). Influence of UV-C radiation on the degree of infection of stored potato tubers by Rhizoctonia Solani Kühn. Agricultural Engineering, 2(154), 35-43.

Lisińska, G. (2006). Wartość technologiczna i jakość konsumpcyjna polskich odmian ziemniaka. Zeszyty Problemowe Postępów Nauk Rolniczych, 511, 81-94.

Maskan, M. (2001). Kinetics of colour change of kiwifruits during hot air and microwave drying. Journal of Food Engineering, 48, 169-175.

Mieszkalska, A., Piotrowski, D. (2014). Wykorzystanie modeli barwy do oceny suszonych surowców roślinnych. Postępy Techniki Przetwórstwa Spożywczego, 2, 105-111.

Páez, C., Reyes, M., Aguilar, C., Pacheco, F., Martíne, E., Orea, A., Bonilla, J. (2011). Control of natural mycobiota in maize grains by ultraviolet (UV-C) irradiation. Acta Agrophysica, 18(2), 375388.

Pasławska, M., Stępień, B., Jałoszyński, K. (2010). Zmiany parametrów barwy owoców jagodowych wywołane suszeniem, przechowywaniem i rehydracją. Inżynieria Rolnicza, 2(120), 95-102.

Pedreschi, F., Leo'n, J., Mery, D., Moyano, P. (2006). Development of a computer vision system to measure the color of potato chips. Food Research International, 39 1092-1098.

Przybylski, W., Jaworska, D., Czarniecka-Skubina, E., Kajak-Siemaszko, K. (2008). Ocena możliwości wyodrębniania mięsa kulinarnego o wysokiej jakości z uwzględnieniem mięsności tuczników, pomiaru barwy i pH z zastosowaniem analizy skupień. ŻYWNOŚĆ. Nauka. Technologia. Jakość, $4(59), 43-51$.

Pytka, K. (2010). Dopasowanie radiometryczne ortoobrazów z wykorzystaniem modelu barw lab. Archiwum Fotogrametrii, Kartografii i Teledetekcji, 21, 341-351.

Reddivari, L., Vanamala, J., Chintharlapalli, S., Safe, S.H., Miller, J.C. Jr. (2007). Anthocyanin fraction from potato extracts is cytotoxic to prostate cancer cells through activation of caspase-dependent and caspase-independent pathways. Carcinogenesis, 28(10), 2227-2235

Rój, A., Przybyłowski, P. (2012). Ocena barwy jogurtów naturalnych. Bromatologia i Chemia Toksykologiczna, 3, 813-816.

Rytel, E., Tajner-Czopek, A., Kita, A., Aniołowska, M., Kucharska, A. Z., Sokół-Łętowska, A., Hamouz, K. (2014). Content of polyphenols in coloured and yellow fl eshed potatoes during dices processing. Food Chemistry, 161, 224-229.

Sakowski, P., Janiszewska, E. (2013). Zmiany barwy soku marchwiowego w czasie obróbki ultradźwiękami. Acta Agrophysica, 20(1), 161-171.

Sansano, M., Juan-Borr'as, M., Escriche, I., Andr'es, A., Heredia, A. (2015). Effect of Pretreatments and Air-Frying, a Novel Technology, on Acrylamide Generation in Fried Potatoes. Journal of Food Science, 80(5), 1120-1128.

Slimestad, R., Fossen, T., Verheul, M. J., (2008). The flavonoids of tomatoes. Journal of Agricultural and Food Chemistry, 56(7), 2436-2441.

Śmigielska, H., Lewandowicz, J., Le Thanh-Blicharz, J. (2013). Wpływ skrobi opornej typu rs4 na barwę i właściwości reologiczne keczupu. ŻYWNOŚĆ. Nauka. Technologia, Jakość, 2(87), 137-149. 
Tomaszewska, M., Neryng, A. (2007). Wpływ środowiska obróbki cieplnej oraz warunków przechowywania na barwę gotowych produktów ziemniaczanych przygotowanych według technologii gwałtownego schładzania. ŻYWNOŚĆ. Nauka. Technologia. Jakość, 3(52), 173-183.

Wierzbicka, A., Hallmann, E., Grudzińska, M. (2015). The content of polyphenols in potatoes depending on the variety and effective micro-organisms. Fragmenta Agronomica, 32(4), 81-88.

Wrolstad, R. E., Smith, D. E. (2010). Color Analysis. In: Food Analysis (Eds. Nielsen S. S.). Springer New York Dordrecht Heidelberg London, 574-586.

Xiuhong, Ji., Rivers, L., Zielinski, Z., Xu ,M., MacDougall, E., Stephen, J., Zhang, S., Wang, Y., Chapman, R. G., Keddy, P., Robertson, G. S., Kirby, C. W., Embleton, J., Worrall, K., Murphy, A., Koeyer, D. De., Tai, H., Yu, L., Charter, E., Zhang, J. (2012). Quantitative analysis of phenolic components and glycoalkaloids from 20 potato clones and in vitro evaluation of antioxidant, cholesterol uptake and neuroprotective activities. Food Chemistry, 133, 1177-1187.

Zapotoczny, P., Zielińska, M. (2005). Rozważania nad metodyką instrumentalnego pomiaru barwy marchwi. ŻYWNOŚĆ. Nauka. Technologia. Jakość, 1(42), 121-132.

Zielińska, M., Markowski, M. (2012). Color characteristics of carrots; effect of drying and rehydration. International Journal of Food Properties, 15, 450-466.

\section{WPLYW PARAMETRÓW NAŚWIETLANIA BULW ZIEMNIAKA ULTRAFIOLETEM W PAŚMIE C NA WYBRANE WSPÓLCZYNNIKI OCENY BARWY FRYTEK WYZNACZONE METODA CIE L*A*B*}

Streszczenie. Ocena barwy, z wykorzystaniem jej wielu parametrów, wykorzystywana jest w odniesieniu do oceny zmian jakościowych produktów, wynikających z zastosowania określonych zabiegów technologicznych. W pracy badano efekty relacji pomiędzy parametrami naświetlania bulw ziemniaka ultrafioletem w paśmie $\mathrm{C}$ na wybrane współczynniki oceny barwy frytek wyznaczone metodą CIE $\mathrm{L}^{*} \mathrm{a}{ }^{*}{ }^{*}$. Wykazano statystycznie istotny wpływ naświetlania UV-C na jasność frytek, zmianę barwy, rozpoznawalność różnicy barwy oraz intensywność odbioru barwy. Analizę statystyczną wyników wykonano na założonym poziomie istotności $\varepsilon=0,05$.

Slowa kluczowe: ziemniak, ultrafiolet, barwa, frytki, CIE L*a*b* 